\title{
The Determination of the Explosive Force of Gunpowder
}

\section{Captain J. P. Morgan R.A.}

To cite this article: Captain J. P. Morgan R.A. (1871) The Determination of the Explosive Force of Gunpowder, Royal United Services Institution. Journal, 15:64, 312-337, DOI: $10.1080 / 03071847109425415$

To link to this article: http://dx.doi.org/10.1080/03071847109425415

册 Published online: 11 Sep 2009.

Submit your article to this journal $₫$

Џ Article views: 3

Q View related articles $₫$ 


\title{
LECTURE.
}

Fridas, March 17th, 1871.

ALajor-Gexeral J. II. LEFROY, O.B., R.A., F.R.S., in the Chair.

\section{THE DETERMINATION OF THE EXPLOSIVE FORCE OF GUNPOTVER.}

\author{
By Captain J. P. MIorast, R.A.
}

Tine subject has been investigated by some very able men, both theoretically and practically; but though the facts thus elicited are very raluable, the conclusions which have been derired from them are not sufficiently harmonious to warrant us in believing that the question has been completely solred.

\section{WHat has BeEx DONe.}

\section{Theoretically.}

The explosive force of gumpowder may be calculated from tho pro. ducts of combustion, on the assumption that certain laws hold good, such as that the tension of a gas varies with its density and also with its temperature. It must, however, be borne in mind that these laws have been verified only within certain limits of pressure and tempera. ture, and, therefore, when wo come to such very great pressures and temperatures as are met with in the explosion of gunpowder, ans conclusions founded on them must be received with caution until the results have been confirmed by experiment.

Robins, about the middle of last century, endeavoured to calculate the force of gunpowder from the amount of elastic fluid produced. He found that the gascous products would occups 244 times the bulk of the powder, at the temperature and pressure of the atmospherc. If this amount of gas were confined in a space of the same size as that occupied by the powder, the pressure would be 244 atmospheres, without making any allowance for the enormously increased tempernture at the moment of combustion. By heating a picce of musket barrel to "the extremest degree of red hot iron"-his assumed temperature of exploded gunpowder-and cooling it in water with certain precautions, he found that the heated air it contained contracted to onc-fourth of its bulk, and concluded that the increase of heat in- 
creased tho clastic force of the gases fourfold. Thus the 244 volumes of gas at the temperature referred to would possess an elastic force of 1,000 atmospheres, or $6 \cdot 7$ tons per square inch.

Gnj-Lussac obtained 450 volumes of gas, and, estimating the temperature at $1000^{\circ} \mathrm{C}$., deduced a pressuro of 2,137 atmospheres (14.5 tons).

Piobert accepted Gay-Lussac's determination of tho quantity of gas produced, but estimated the temperature at $2400^{\circ} \mathrm{C}$., and thus deduced a pressure of between 4,000 and 5,000 atmospheres for the permanent gases alone. Counting the other products, which at this temperaturo he considered would be in a state of vapour at a high tension, ho estimated the total pressuro at 9,600 atmospheres (64 tons).

With regard to the solid products, he says:- *

"There thus exist two very distinct periods during the continuance : of the phenomenon of explosion; the first during which the products $\therefore$ are in the stato of clastic fluids, the tension of the vapours adding : themselves to those of the permanent gases; and the second period "during which the permanent gases alone act, the rapours being con"densed, and forming those residues of combustion termed 'crasse, "and which deposit themselves on the sides of the chamber in which "the powder is shat up, because these products hare not been able to " escape during the time they were in the gascous state.

"The explosion of powder may thus present great anomalies in the "cffects produced from one point of action to another, when the "elastic fluids act only during the first period, which is that of "grcatest effort, and this should be taken into consideration every "time the circumstances of firing do not remain identically the same; "also the force of powder measured during this period has given riso " to a great many valuations very different from one another; when, on "the contrary, the force of the powder is measured after these effects, "during tho second period, it is estimated at much less than it is in "reality, because in this case no account is taken of the tension of the "vapours which no longer exist."

Bunsen and Schischkoff obtained 193.1 volnmes of gas, the production of which was attended by the development of 619.5 units of heat, and from this, taken in conjunction with the known capacities for hent of the products, they concluded that the temperature of the flame of powder, cxploded in a closed space so that the gases cannot freely rexpand, is $3340^{\circ} \mathrm{O}$. With regard to the residue, they say :- $\uparrow$

"Although a slight volatilisation cannot be denicd, it may be shown "from the calculation of the temperature of the flame that the tension "caused thereby cannot amount to one atmosphere. The temperatare " of the flame of hydrogen burning in air is $3259^{\circ} \mathrm{C}$. $\Delta$ fragment of "powder residne fused on a thin platinum wire was gradually vola" tilised in a jet of hydrogen burning in air, bat it never reached " cballition, and hence the tension of its vapour could never have "attained one atmosphere."

* Traite d'Artilleric théorique et pratique.

† Occasional Papers, Rojal Artillery Institution. 
They concludo that the pressure can never rench 4,500 atmospleres (30 tons).

Mr. Abel emarks, " "The conclusions to which Bunsen and Schisch. "koff have been led by their elabornte investigation of the products of " decomposition of gunpowder are, in the most important respects, so "greatly at varianco with the views hitherto adopted respecting tho " general nature of the chemical clanges involred in the explosion of "gunpowder, and cousequently, with reference to the sereral con"ditions which influence the degree of forco exerted by the explosion, "that all who are interested in the considerations embraced in tho " research of these chemists, will be inclined to serutinize closely the " means by which thes have arrived at their resnlts before accepting "them as likely to represent correctly the effects obtained by the " employment of gunpowder in practice."

Their errors lie in their supposing that the products they obtained are the same as exist in the gun during the time of maximum effect. The solid residue, which forms about two-thirds of the total charge, is mainly carbonate and sulphate of potash. Mrr. Bloxamt informs me that, from the appearanco of this residue after deposition, he is decidedly of opinion that it has been deposited from the gaseons state. Further on we shall see that Rumford's experiments support this riew. Wo are therefore at liberty to assume with Piobert that there are tro actions, one during the time of greatest heat and pressure, and another afterwards. We may eren go further than Piobert, and supposo that the solid products aro not only in the gaseous state, but to a certain extent decomposed by the high temperatare, in accordance with a chemical law, of which there are numerous examples, such as the decomposition of carbonic acid into carbonic oxido and oxygen at a high temperature, or of water into hydrogen and oxfgen by the heat of the clectric spark.

Keeping these considerations in view, $I$ have prepared a formula which appears to bo a very reasonable one. In the opinion of Professor Bloxam, to whom $I$ hare submitted it, wo know so little of the effects of such extremely high temperatures upon the substances remaining after the explosion. of powder, that the supposition is as allowrable as any other. It is this:-

English powder, with onc-quarter per cent. less nitre, gires an exact chemical formula which wo may suppose to decomposo thus :-

$$
6\left(\mathrm{KO}^{\mathrm{N} \mathrm{NO}_{5}}\right)+20 \mathrm{C}+5 \mathrm{~S}=20 \mathrm{CO}+5 \mathrm{SO}_{2}+6 \mathrm{KO}+6 \mathrm{~N} \text {. }
$$

Tho method of calculating the amount of gas produced, with tho temperature and resulting pressure, is as follows :tion.

* Chemist to the War Department, Occasional Papers, Rogal Srtillerg Institu-

† Professor of Chemistry, Fing's College, London, Adraneed Class of Lrtiliery Oficers, \&c., \&c. 


\begin{tabular}{|c|c|c|c|c|c|c|}
\hline Constituents. & $\begin{array}{l}\text { Units of } \\
\text { Jicat } \\
\text { erolred. }\end{array}$ & Products. & $\begin{array}{l}\text { Tolumes } \\
\text { of } 23 \cdot 3 \\
\text { cub. in. }\end{array}$ & $\begin{array}{c}\text { Weight } \\
\text { in } \\
\text { grains. }\end{array}$ & $\begin{array}{l}\text { Specific } \\
\text { heat. }\end{array}$ & $\begin{array}{l}\text { Units of } \\
\text { heat required } \\
\text { to raiso } \\
1^{\circ} \mathrm{C} \text {. }\end{array}$ \\
\hline \multirow[t]{2}{*}{$\begin{array}{r}20 \mathrm{C} \ldots \ldots . \\
5 \mathrm{~S} \ldots \ldots . . \\
6\left(\mathrm{~K} O . \mathrm{NO}_{5}\right) .\end{array}$} & $\begin{array}{l}297720 \\
176000 \\
. .\end{array}$ & $\begin{array}{l}20 \mathrm{CO} \\
5 \mathrm{SO} . \\
6 N \\
\text { GKO }\end{array}$ & $\begin{array}{l}40 \\
10 \\
12\end{array}$ & $\begin{array}{r}280 \\
160 \\
81 \\
283\end{array}$ & $\begin{array}{l}\cdot 17.4 \\
\cdot 11 \\
\cdot 17.4 \\
\cdot 17.4 ?\end{array}$ & $\begin{array}{l}48 \cdot 52 \\
17 \cdot 6 \\
14 \cdot 616 \\
40 \cdot 068 \\
\end{array}$ \\
\hline & 473720 & & 62 & 806 & & 130 \\
\hline
\end{tabular}

Thus 806 grains of powder produce 62 rolumes or 1444:6 cubic inches of gas at $0^{\circ} \mathrm{C}$., and 1 atmosphero pressure ; and, consequently, 1 cabic inch, or 240 grains, will produce 430 cubic inches of gas at the same temperaturo and pressure. The temperature of the products ocenpjing 430 times tho powder space will be $\frac{473720}{130}=3644^{\circ} \mathrm{C}$, and the pressare, supposing the solid potash to occupy one-third of the space, will be $=\frac{3}{3} \times 430(1+\cdot 00366 \times 3614)=9250$ atmospheres, or 62 tons per square incll.

Exception may be taken that no heat is here allowed for the decomposition of the nitre, nor for the latent heat of the gases erolved from it. But I may observo that, in all componnds containing nitrogen, tho clcments are very readily decomposed, and in some cases, such as nitrous oxide, heat is actually erolred by the separation of the atoms. The units of heat were obtnined by Bunsen and Schischkoff with tho gases expanded and mach latent heat absorbed; but, in passing from the liquid to the gascous state under great pressure, the law has been established that no latent heat is absorbed, and vice versia. We may therefore consider tho temperature arrived at as not rery different from that which exists at the moment of explosion, for any absorption of heat by decomposition nould probably be more than counterbalanced by the heat which would be evolved if we wero to reduce the 430 rolumes to $\frac{a}{3}$ of a rolume.

It is possible that the temperature may eren bo higher, and the pressure deduced is by no means the limit which might be attained, but is rather to be considered a minimum than a maximum, scoing that the products may bo in a still further state of decomposition than has been assumed; for it is mell known that at a high temperature carbon will reduce potassa; the tendencs also of potassium to pass into rapour is well known. It is possible therefore that in the presence of carbonic oxide, and at such a temperature, the elasticity of the two rapours of potassium and oxygen may be sufficient to cause decomposition, and thus we should have all the products in the state of rapour with a corresponding augmeutation of pressure.

This is not at all unlikely, for in tho cases of gun-cotton and nitrogljccrine, the products of decomposition are much more dissociated by 
being exploded in a confined space than when burned in the air. In their case the products, being carbonic acid, carbonic oxide, nitrogen, and aqueous rapour, have no tendency to rennite, and can be recorered in the very state in which they were at the time of maximum pressure; but, in the case of ganpowder, one of tho products is potassium or potassa, whose strong basic attraction causes recombination, so that none of the other products, nitrogen only excepted, can remain free. until it is satiated.

These considerations show, almost with absolute certainty, that the products olbtained by the combustion of powder are not the same as cxist in the gun during the time of greatest action, and wo thus get rid of a difficulty which wonld tend to prevent our accepting the bigh pressares which we shall sec are obtained by experiment.

Another consideration in favour of a possible high pressure is the limit to which the laws applicable to gases can bo carried. At some point the liquid form wonld bo assumed; and, though with low temperatures, the increment of pressure diminishes as the liquid form is approached, the same does not appear to hold good as the temperature is increased. Carbonic acid gas, so far as is known, cannot bo liquefied abore $80^{\circ} \mathrm{F}$. With high temporatures the pressure may increase very greatly when the density is great. It may eren approach the law of water pressure, which wo know increases enormously with a small diminution of balk. Thus even theoretically, the pressure may attain an amount which it would be impossible for us to restrain with all tho appliances at our command.

It is necessary that we should have clear ideas on this point, as we shall see it is the slowness and regularity of the combustion of gunpowder that are the elements which make it possible to utilise its cnormous pressure and keep it under control; and, to be of any practical use to us, eren were we to know exactly wlint are the products of com. bustion, we must also know

\section{The Rate of Combustion.}

Robins made a very ingenions experiment to determino whether the explosion of gunporder was instantancous or not. He says:- *

"If part. only of the porder is fired, and that successively, then, by " laying $n$ larger weight before the charge (suppose two or threo ballets $\because$ instcad of onc) a greater quantity of powder will necessarily bo fired, "since a heavier weight would be a longer time in passing throngh the " barrel. Whence it would follow that two or three bullets would be " impelled with a much greater force than one only. But the contrary " of this appears by experiment; for, firing two and three bullets laid " contiguous to ench other with the same charge respectively, I bare "fond that their velocities were not much different from the reciprocal " of their sub-duplicates of matter."

Thongh Robins, in accordance with his deductions of a small initial pressure, might have been prepared to accept the result he here states, yet others, who knew that his estimate was mnch too low, could not accept his conclusion, secing that, if gunpowder were burnt in its own

* Encr. Brit. "Gunnerr." 
space, no possible gun could withstand its explosive effects. It is to be remembered, however, that Robins made all his experiments with small arms, where the nature of tho powder used would make the actual facts of the case approximate so closely to his deductions as to defy detection by the rude method ho employed. Any windage would allow a greater escape of gas as the number of bullets increased, and, though the pressure might bo greater at the commencement of the bullet's motion, such a loss would give rise to a diminished pressure after. wards. Sir Wm. Armstrong mentions another circumstance in connection with this :-

"By using a slower burning powder, less heat and pressure are is erolved at first, and the waste of heat in the stago of initial pressure " being less, more heat remains for expansive action. Hence the "slower burning powder is weaker at first but stronger afterwards, "and, although the total quantity of gas be only the same, and tho " pressure not so great at any point, jet the aggregate pressure through" out the bore may equal that of the more energetic and moro dangerons "powder."

It is not surprising that Robins should hare failed to detect all the points of a most difficult question on which long experience alone has succeeded in shedding bat even yet a faint light. The wonder is that living in the time he did, he should have discovered so much. When he took up the question, gunnery was not a science, but was very much in the state in which Newton found astronomy. The subject had to some extent been treated in a rude practical way, and wild speculations had been made as to the nature of the forces at play, but the matter had never once been scientifically approached. The fact, too, that all his results, obtained with the aid of small arms, have in tho main been found to extend to the biggest guns without the discorery of any new law, must always make Robins occupy the first place in the estimation of every artilleryman.

The question of the instantaneous explosion of gnnpowder is one of extrcme importance, for, independently of the increase of the actual amount of pressure which it would cause in a gan, it has another bearing on the subject of almost equal importance. In a paper read here last year, $f$ l have giren a rigid mathematical demonstration which shows that a sudden pressure has trice the destructire effect on a gun that the same pressure would have if slowly applied. Mr. Mallet also has illustrated this point very clearly, by showing that a weight would bend a support twice as much when suddenly applied as it would when slowly applied. Any ono can test it with a spring balance.

Long experienco has shown that it lies in our power to rary the rate of combustion of gunpowder, and in this gunpowder differs very much from gan-cotton. In gun-cotton the instability which renders explosion possible is brought about by chemical action, so that atom finds atom in closest proximity ready for immediate recombination if only sufficient temperature be attained. In gunpowder, on the contrary,

- Address as Prcsident of the Institution of MIechanical Engincera, Newcastlo meeting, 1869.

† Vol. xiv.; p. 479.

YOL. $\mathbf{X Y}$. 
the instability is prodnced by mechanical mixture, and, on a minute scale, the particles of charcoal aro burned like coals in a fire. With gunpowder in its rude state, the difficnlty was to get the particles close enough together to make tho combustion sufficiently rapid, and it was not till the importance of thorough incorporation was understood, that any real progress was made in rendering it a destructive agent. Even with thorongli incorporation, it was necessary to provide for the rapid ignition of the various particles, for the combustion could not travel with sufficient rapidity through the entire mass. To make the action cnergetic enough, it was necessary, as it were, to light the fire in a great many places. Granulation efiects this by allowing the flame from one point of ignition to spread throughout the charge and ignite all the grains very nearly simultaneously. It also has the good effect of preventing any separation of the ingredients when once thoroughly incorporated. Thas the action depends on the rapidity of ignition of the grains, and the rite of combustion of each grain. The rapidity of ignition of the grains depends on the size of the spaces between the grains, and the rapidity of combustion on the smallness of the graine themselres; but as these aro opposed to ono another, we can readily sec that with some size of grain, which is most favourable to both requirements, the combustion of the whole charge will be the most rapid. Small grains will burn rapidly, but the spaces between them being also small, the ignition will not be so rapid. Iarge grains will burn slowly, but will admit of rapid ignition. The shape of the grain ls another element to bo considered, bnt ono of still more importance is the density, for, if the grain be porous, the flame will not only pass between the grains, but also penetrate into their mass. We shall obtain the most rapid combustion, therefore, by combining a certain size and shape of grain with a certain density of grain; and, if wo wish to moderate the rate of combustion, we must not only increase the size of the grain, but also increase its density, especially in large guns, where the pressure is very great.

The objects to be attained in regulating the size and density of the grains are, the greatest possible velocity of projectile combined with the least etrain on tho gun. These cannot be obtained by one set of conditions for all natures of ordnance. A small projectile moves quickly, and relieres the strain in a still greater ratio. $A$ heary projectile not only mores slowly, bat even a considerable motion does not reliere the strain in a proportionate manner, because the column of powder is longer in a large than in a small gan. With small arms, consequently, wo must use fine grain powder, but large grain powder with heavy guns. Owing to the effect heat and pressure hare in accelerating the combustion, we cannot determine $\grave{a}$ priori what size or density of grain will suit any particular gun. This, and as a consequence tho actual pressure in the gun itself, can only be determined.

\section{Practically.}

Rumford was the first who attempted to obtain the pressure of gunpowder by actual experiment. Not being able to find any material strong enough to confine it when exploded in its own space, he measured 
Jounal R U.S.Institutión.

Yol.15.

Pl. XII.
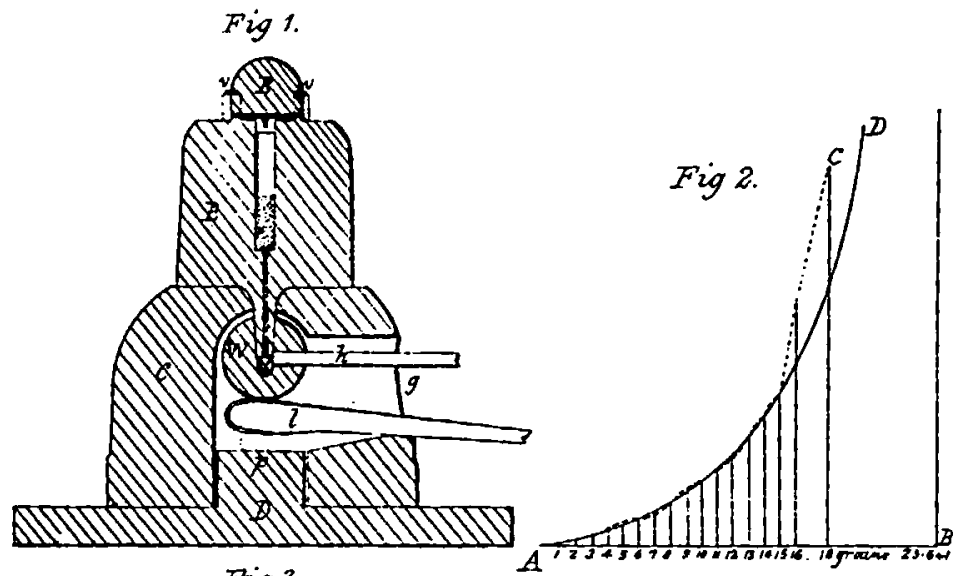

Fig 3

Fig 5.
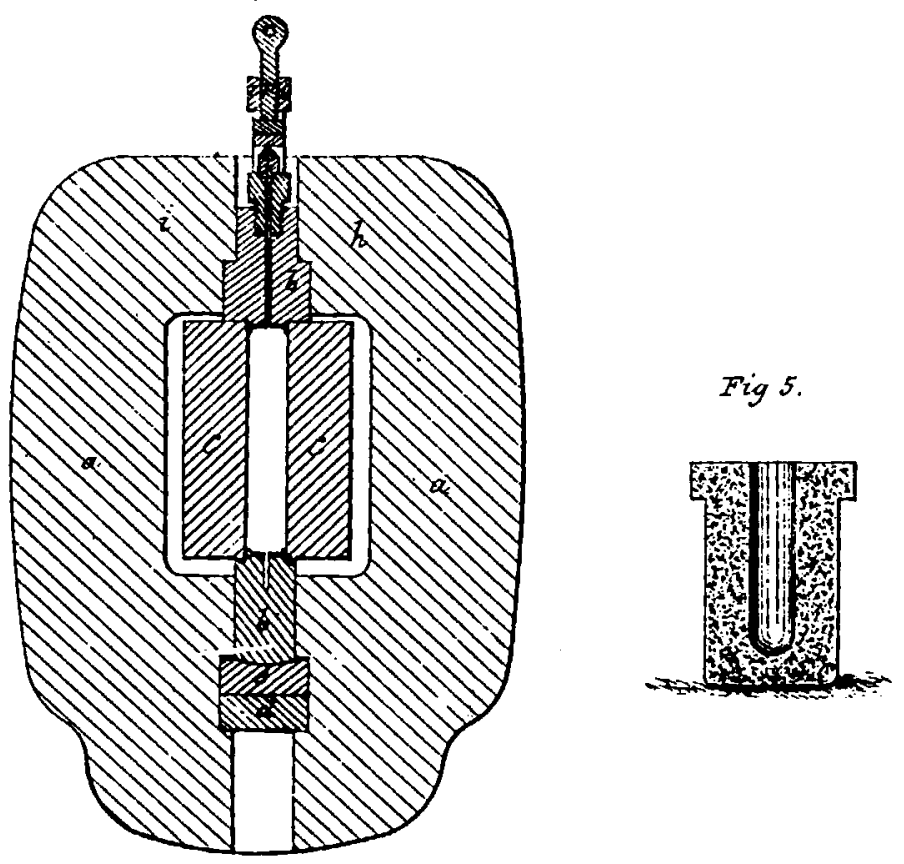

Fig 4.

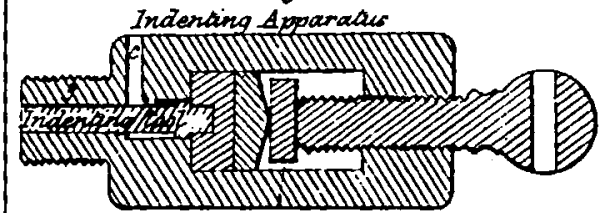


the pressuro when exploded in closed spaces baring various relations to the bulk of the charge, and had it been possible to combine this method with a knowledge of the rato of combustion, he would hare completely solved the question. The plan he adopted was to make a gmall, short, strong gun, the muzzle of which he confined with a heary wejght, varying the charges and so regulating the weight that tho force of explosion was just safficient to lift it.

In this way he obtained the rarious pressures, and made a calculation of what the pressure would be if the charge were exploded in its own space. No vent or escapo of any kind was allowed. Tho chargo was fired by means of a red-hot ball, which communicated the heat through the walls which contained a long narrorr chamber at tho base of the charge. Fig. 1* shows the method used; the enclosing weight was placed on tho top, anä is not shown.

The bore was $\frac{1}{4}$ inch diameter at the top, and the actual capacity of the whole gun was $25 \frac{1}{2}$ grains.

The following table gives the pressures obtained with a varying quantity of powder in grains. Tho first column gires the actual pressures, the second the pressures calculated according to what appeared

\begin{tabular}{|c|c|c|c|}
\hline \multirow{2}{*}{$\begin{array}{l}\text { Chargo in } \\
\text { grains. }\end{array}$} & \multirow{2}{*}{$\begin{array}{l}\text { Ratio of } \\
\text { charge to } \\
\text { space. }\end{array}$} & \multicolumn{2}{|c|}{$\begin{array}{l}\text { Pressure in tons per } \\
\text { square inch. }\end{array}$} \\
\hline & & Measurcd. & Calculnted. \\
\hline $\begin{array}{r}1 \\
2 \\
3 \\
4 \\
5 \\
6 \\
7 \\
8 \\
9 \\
10 \\
11 \\
12 \\
13 \\
14 \\
15 \\
16 \\
17 \\
18 \\
15 \\
20\end{array}$ & $\begin{array}{l}\cdot 039 \\
\cdot 078 \\
\cdot 117 \\
\cdot 150 \\
\cdot 195 \\
\cdot 23-1 \\
\cdot 273 \\
\cdot 312 \\
\cdot 351 \\
\cdot 300 \\
\cdot 420 \\
\cdot 469 \\
\cdot 507 \\
\cdot 5 \cdot 16 \\
\cdot 555 \\
\cdot 621 \\
\cdot 663 \\
\cdot 702 \\
\cdot 741 \\
\cdot 780\end{array}$ & $\begin{array}{r}\cdot 5 \\
1 \cdot 2 \\
1 \cdot 5 \\
2 \cdot 5 \\
3 \cdot 7 \\
4 \cdot 6 \\
5 \cdot 6 \\
7 \cdot 8 \\
10 \cdot 3 \\
12 \cdot 6 \\
14 \cdot 8 \\
17 \cdot 1 \\
21 \cdot 9 \\
26 \cdot 7 \\
31 \cdot 5 \\
47 \cdot 3 \\
73 \cdot 3\end{array}$ & $\begin{array}{r}\cdot 5 \\
1 \cdot 1 \\
1 \cdot 8 \\
2 \cdot 6 \\
3 \cdot 6 \\
4 \cdot 8 \\
6 \cdot 2 \\
7 \cdot 8 \\
9 \cdot 8 \\
12 \cdot 1 \\
14 \cdot 9 \\
18 \cdot 1 \\
22 \cdot 0 \\
26 \cdot 5 \\
31 \cdot 9 \\
38 \cdot 2 \\
45 \cdot 6 \\
5 \cdot 6 \cdot 3 \\
61 \cdot 5 \\
76 \cdot 5\end{array}$ \\
\hline 251 & $1 \cdot$ & & $19 \cdot 1 \cdot 5$ \\
\hline
\end{tabular}

* The Institution is indebted to tho Rogal Artillery Institution, Woolrich, for the use of the stones to illustrate this paper.-ED. 
to bo a law. Sometimes the weight was lifted with an explosion like that of a gin, at others it was not raised at all. The result was taken when it was just lifted with a very small escape of gas.*

The curre in Fig. 2 shows the calculated pressures. They agree very well with the measured pressures up to 15 grains. The pressures afterwards are calculated without taking into account the higher pressures, which appeared to manifest themselves as the cannon began to fail. If these higher pressares were taken into account, Rumford considered that 100,000 atmospheres, or nearly 700 tons, would not be too great an estimate of the forco of powder exploded in its own space. Piobert, however, considers that the higher pressures were probably due to the yielding of the metal at the top as it began to fail.

Observing that when the space is three times that of the charge the pressure is, in round numbers, 10 tons; when it is trice, 20 tons; once and $a$ half, 40 tons; and once and a quarter, 80 tons; a very simple empirical formula, applicable to guns, may be given, founded on the supposition that the pressure raries inversely as the amount of extra space which is added to that of the charge consumed :-

$$
\begin{aligned}
& \text { If } P=\text { pressure in tons, } \\
& l=\text { length of charge, } \\
& y=\text { proportion of charge consumed } \\
& x=\text { distance mored by the shot, } \\
& P=\frac{20 y}{\frac{x}{l}+1-y}
\end{aligned}
$$

"What was very remarkable in all the experiments in which the "generated elastic vapour was completely confined, was the small " amount of expansive force which the rapour appeared to possess " after it had been suffered to remain a few minutes, or even only a "few seconds, confined in the barrel, for, in raising the weight by " means of its lever, and suffering this rapour to escape, instead of "cscaping with a loud report it rushed out with a hissing noise hardly "so loud or so sharp as the report of a common air-gun, and its effects "against the leathern stopper by which it assisted in raising the "weight were so very feeble as not to be sensible. On examining the " barrel, however, this diminution of force in the generated elastic fluid " was easily explained; for what was undonbtedly in the moment of " explosion in the form of an elastic fluid, was now found transformed " into'a solid body, as hard as a stone.

"That this hard substance, found in the barrel after an explosion in " which the generated elastic fluid had been completely confined, was "actually in a fluid or elastic state in the moment of explosion, is " ovident from hence, that in all those cases in which the weight was " raised and the stopper blown out of the bore, nothing was found "remaining in the barrel. It was very remarkablo that this hard sub. "stance was not found distributed about in all parts of the barrel " indifferently, but more of it was always found near the middle of the

* Philosophical Transactions of the Rojal Society of London, 1797. 
"length of the boro than at either of its extremities; and the upper part " of the vent-tube :n particular was always found quito filled with it. It " shonld seem from hence that it attached itself to those parts of the " barrel which were soonest cooled; and hence the reason, most pro"bably, why none of it was ever found in the lower part of the rent" tube, where it was kept hot by the red-hot ball by which the powder "was set on fire."*

A better plan than that adopted by Rumford for measuring tho actual pressure cannot bo conceived. Wo have considered the nature of a suddenly applied pressure in doubling the strain on yielding material, but a suddenly applied pressure in this case would make no difference, for the absolute weight keeping the powder enclosed would not yield to any pressure less than itself, and so would show the same result whether tho pressure were suddenly or slowly applied.

There is, however, another kind of pressure to be considered. It was investignted by Robins in the following manner. By fring a musket charged with a light rad against a pendulum he considered the velocity of foreed gunpowder to be 7,000 feet seconds. He says:-

"From these determinations may be deduced the force of petards, " since the action depends entirely on the impulse of the flame, and it " appears that a quantity of powder, properly placed in such a machine, " may produce as violent an effect as a bullet twice its weight moving " with a reiocity of 1,400 or 1,500 feet per second." $\dagger$

In order to discover what effect this action had on the velocity of the bullet, Robins placed 12 pennyweights of powder at the bottom of a musket and a bullet $11 \frac{1}{4}$ inches from the bottom of the bore, and found that the relocity imparted was 1,400 feet per second instcad of a calcalated velocity of $1,200 \mathrm{f}$. $\mathrm{s}$. without the action in question. Then the same quantity of power was scattered through the whole space the velocity was only $1,100 \mathrm{f}$. s.

By placing a bullet 16 inches in front of the charge in a "good Tower "musket," he found that "the part of the barrel just behind the bullet "was swelled out to donble its diameter, like a blown bladder, and two " largo pieces 2 inches long were barst out of it."

We have every reason to beliere that the action here referred to does exist, and also that it is local and does not extend throughout all the space in which the pressure of the powder acts. Under these circumstances the thinner the confining surface at the point of action the more injurious would be the effects produced. With a thick wall, as in a gun, the action would be more distributed, and, though it might indent the surface of the bore as by a blow, it might not succeed in endangering the structure of the gun. For the same reason it is moro than likely that any action of the sort would not appreciably interfere with Rumford's results, as well on account of the great mass on which he received the pressure as on account of the fact that a small motion of the weight had to take place before any gas could escape.

It will be observed, however, that though Rumford's experiments are most valuable in showing the extraordinary force of fired gunpowder and

* Philosophical Transactions of the Rogal Socicty of London, 1797.

+ Ency. Brit. "Gunnery." 
its pressure rhen occupying various spaces; jet, becauso they leavo out of account the rate of combustion, on which mainly depends the amount of relief given by the motion of a shot in a gan, they do not help us practically. We consequently find that succeding experimenters havo turned their attention to some method of determining the explosire force of powder which includes this most important element.

Rodman is the next whose experiments we must consider. $\mathrm{He}_{\mathrm{c}}$ cndearoured to measure the pressure in the bore from the recoil of the gun, swung as a pendulum. bycansing it to trace a curre on a revolving cylinder. $\Lambda$, howerer, the whole space of recoil was less than an inch, nothing more than a general outline of the pressure conld be obtained. Ho sass:-*

"The curves described show that the gun and shot had acquired " onc-half of their final relocity in about one-fourth of the time required "for the shot to pass from its seat to the muzzle of the gun; thereforo "the mean pressure in the bore of the gun, during the first fourth of "that time, must hare been double that for the whole time, or = " 18,132 lbs. ( 8 tons) per square inch. They further show that the "shot and pendulum had acquired one-fourth of their final relocity in " about one-sixteenth part of the wholo time aforesaid, and that the " mean pressure during the first sixteenth part of that time was = " 36,264 llus. ( $16 \cdot 2$ tons). And the pressure will be still greater during "the lower rates of velocity, amounting to probably 50,000 lbs. (22.3 "tons) per inch; and this estimate is for a statical pressure, the strain "due to which, as will be shown further forward in this Report, must " be considerably less than the actual strain, the rate of application of "the force affecting the strain to which it subjects the resisting body, "so far as eren to double it in the extreme case, or when the applica"tion of the force becomes instantaneous."

He conducted a much more elaborate and raluable series of experiments to ascertain in the very bore itself what was the actual pressure at each point. In order the better to judgo of the ralue of his deductions, it is hecessary to give. a short account of some preliminary experiments which wero made with hollow cylinders to test their strength.

Major Wade gives the hydrostatic pressures necessary to barst castiron hollow cylinders cut from the chase of a 6-pounder gun, of onequarter and one-half calibres thickness, compared with the tensile strength of the iron.t

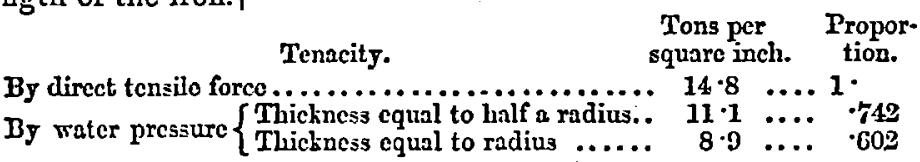

These pressurcs agrec so well with what might be expected from the law of decrease of proportionate strength as the thickness increases, that I haro no hesitation in accepting. them as correct. The law of decrease only holds strictly as far as the elastic limits up to which the

* Experiments on JIctals for Cannon and Cannon Porder. Rodman.

+ Reports of Experiments on Mietals for Cannon, by Oficers of the Ordnance Department, United States' drmy. 
cxtcnsion is uniform; beyond the elastic limits the extension increases more rapidly than the strain. Thus there is a slight increase of the proportion of strength given when the thickness was one-half calibie, which by calculation would otherwiso be equal to half the teusile strength of the metal.

Rodman tested similar cylinders with gunpowder. The cylinders, like the last, Inad the column of metal in the walls of the same length as the hore on which the pressure acted. The length was 12 inches, and the calibre 2 inches. The thickness of metal was varied. The following table shows the actual pressures measured when these cylinders were burst by powder exploded in the interior. Alongside the actual pressures is giren a set of pressures calculated according to the law which regulates the strength of hollow cylinders, and made to agree with the instance in which the thickness of metal was one-half calibre in Rodman's experiment, the particular thickness being chosen because it required two charges to burst it, and may thereforo be con. sidered as just burst, and no more (sce Fig. 3).

I have giren IIajor Wade's hydrostatic bursting pressures for comparison.

\begin{tabular}{|c|c|c|c|}
\hline Thickness of metal. & $\begin{array}{l}\text { Mfean bursting } \\
\text { pressure by } \\
\text { experiment. }\end{array}$ & $\begin{array}{l}\text { Computed } \\
\text { bursting } \\
\text { pressure. }\end{array}$ & $\begin{array}{l}\text { Hydrostatic } \\
\text { bursting } \\
\text { pressure. }\end{array}$ \\
\hline 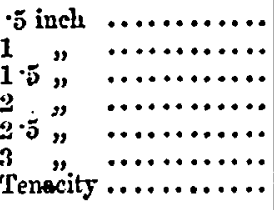 & $\begin{array}{l}16 \cdot 9 \text { tons. } \\
17 \cdot 1 ", \\
23 \cdot 3 \quad " \\
35 \cdot 8 \quad, \\
41 \cdot 2 ", \\
41 \cdot 8 ", \\
12 \cdot "\end{array}$ & 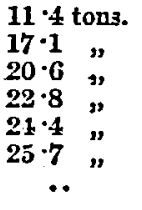 & $\begin{array}{c}5 \cdot 5 \text { tons. } \\
8 \cdot 9 " \\
\ldots \\
\ldots \\
\ldots \\
\ldots\end{array}$ \\
\hline
\end{tabular}

It will be noticed that eren in the most farourable caso for com. parison, viz., that in which the cylinder was just burst, tho pressure obtained bj gunpowder was about double the hydrostatic pressure. This is a rery serions discrepancy, and is sufficient to cast a doubt on the accuracy of his method of measuring the pressure, Which was by fixing a "pressure gauge" in the gun at rarious distances along the bore. The pressure was inferred from the distance an indenting tool was pressed into a wrought iron or copper specimen, the force necessary for any particular indentation laving first been obtained by statical pressurc.

Fig. 4 shows this gange.

Rodman tried the effect of varying the charge and shot in a gun. He fired a $43 \mathrm{lb}$. round shot with charges rarging from 3 to $12 \mathrm{lbs}$., and found that the pressure varied very accurately as the charge; he also fired from the same gun, with a fixed charge of 5 lbs., shot rarying from 35 to $85 \mathrm{lbs}$., and again found that the pressure raried with tho shot:" He says :-*

* Esperiments on Metals for Cannon and Cannon Powder. Rodman. 
"The nearest approximation to any regalar law of variation of pres"sure due to variation of charge and projectile, discoverable in the " results obtained from the series, with a constant reight of projectilo " and variablo weight of charge, and that with a constant weight of " charge and variable weight of projectile is, that with a constant " diameter the pressure increases directly as the product of the weight " of the charge by that of the projectile."

This law is much severer than that of Rumford, and, unless we account for it by his method of measuroment being inaccurate, To must do so by concluding that the rato of combustion increased with the charge and projectile on account of the greater heat and pressure developed."

He next tried varying the bore, with the following results:-

"Table showing the velocity of shot in feet per second, and pressure of "gas per square inch (in tons) due to cqual colnmns of powder " behind equal columns of metal, when fired in guns of different " diameters of bore, each result being a mean of ten fires.

\begin{tabular}{|c|c|c|c|c|c|c|c|c|c|c|c|}
\hline \multirow{2}{*}{ 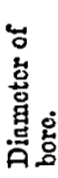 } & \multirow[b]{2}{*}{ 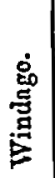 } & \multirow{2}{*}{ 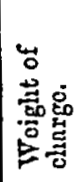 } & \multirow{2}{*}{ 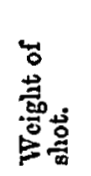 } & \multirow{2}{*}{$\begin{array}{l}\dot{\infty} \\
\stackrel{4}{0} \\
\stackrel{5}{0} \\
\dot{0} \\
\stackrel{0}{0}\end{array}$} & \multicolumn{7}{|c|}{ Pressure at different distances from bottom of bore. } \\
\hline & & & & & 过 & 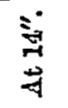 & 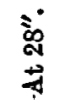 & $\begin{array}{l}\text { ⿳亠ें山ें } \\
\text { 光 }\end{array}$ & $\begin{array}{l}\dot{8} \\
2 \\
+\end{array}$ & 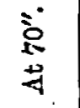 & 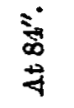 \\
\hline $\begin{array}{c}7^{\prime \prime} \\
9^{\prime \prime} \\
11^{\prime \prime}\end{array}$ & $\begin{array}{l}\cdot 07^{\prime \prime} \\
.09^{\prime \prime} \\
\cdot 11^{\prime \prime}\end{array}$ & $\begin{array}{c}\text { lbs. } \\
5 \cdot 13 \\
8 \cdot 48 \\
12 \cdot 67\end{array}$ & $\begin{array}{c}\text { lbs. } \\
74 \cdot 44 \\
124 \cdot 42 \\
186 \cdot 03\end{array}$ & $\begin{array}{l}904 \\
888 \\
927\end{array}$ & $\begin{array}{l}16 \cdot 3 \\
30 \cdot \\
38 \cdot 7\end{array}$ & $\begin{array}{r}7 \cdot 1 \\
9 \cdot 4 \\
13 \cdot 1\end{array}$ & $\begin{array}{r}3 \cdot 7 \\
7 \cdot 9 \\
12 \cdot 4\end{array}$ & $\begin{array}{r}2 \cdot 9 \\
6 \cdot 7 \\
10^{-}\end{array}$ & $\begin{array}{r}3 \cdot 1 \\
13 \cdot 1 \\
12 \cdot 7\end{array}$ & $\begin{array}{r}3 \cdot 6 \\
9 \cdot 4 \\
15 \cdot 1\end{array}$ & $\begin{array}{c}3 \cdot \\
10 \cdot 2 \\
11 \cdot 2\end{array}$ \\
\hline
\end{tabular}

"The points most worthy of note in these results are the very marked "increase in the pressure of gas as the diameter of bore increases, and " that the indications of pressure are greater at 56,70 , and 84 inches " than at 42 inches, especially in the 9-inch and 11-inch guns."

The forner Rodman accounts for by tho greater heat dereloped in a large than in a small charge. The small bore, too, abstracts a greater proportion of leat by means of the walls of the gun, and also allows a greater proportion of gas to escape by means of the vent. The increase of pressaro towards the muzzle he believes "to be due to the more "violent and sudden contraction in the thin than in the thick part of " the gan. . - For in the thick part of the gan the pressure is " much less rapidly developed, and subsides much more gradually, the "contained gas forming an elastic cushion, which would, if the bore "were long enough, allow this part of the gun to retarn from its "strained to its free condition, without any vibration at all : while in "the muicl used in these experiments the pressuro is almost instan"taneonsly developed and as suddenly subsides in the chase of the "gan, so that while the indenting piston is on its ray outward, it is " saddenly met by the retarning specimen, which is drawn in along 
"with the housing by the contraction of the gun, with such violence " as to amount in effect.to a smart blow of the indenting tool against " the specimen. Close examination shows a number of marks or cuts " of tho indenting tool on the specimen in this part of the gan, caused " by the tool not striking in the same place nt each vibration of the “gun."

If this explanation bo the true one, it may account for the unsatisfactory results giren by his gauge as to absolute pressures. That it does not give the absolute pressures is manifest, for in the $11^{\prime \prime}$ gun, wo find the pressure per square inch throughont tho boro more than double that of the $7^{\prime \prime}$, and yet the resulting velocities remain the same, or nearly so. It is possible that it may represent the destructire action on the gun; and may be accounted for by a sudden pressure which sets up vibration in the powder-chamber to bo continued throughout the bore, the greater intensity towards the muzzle being duo to the same cause, which makes the waves of the sea more riolent as thoy come into shallow water.* That, however, the destructive action on the walls is the same in amount as that indicated by the ganges cannot bo relied on, because the action shown by the gauges is the result of the compound vibration of both walls and indenting tool.

He also tried the effects of varying the size of the grain of powder with the following results :-

"Table showing the relocitics of shot and the pressure of gas, due to " equal charges of powder, of the same composition, and differing "only in size of grain-each result being the mean of five fires"with the 11" gun, the same shot being used in all the fires.

\begin{tabular}{|c|c|c|c|c|c|c|}
\hline \multirow{2}{*}{$\begin{array}{l}\text { Diamcter } \\
\text { of grain. }\end{array}$} & \multirow{2}{*}{$\begin{array}{l}\text { Weight of } \\
\text { charge. }\end{array}$} & \multirow{2}{*}{$\begin{array}{l}\text { Weight of } \\
\text { shot. }\end{array}$} & \multirow{2}{*}{$\begin{array}{l}\text { Initial } \\
\text { relocity. }\end{array}$} & \multicolumn{3}{|c|}{ Pressuro of gas in tons. } \\
\hline & & & & At bottom. & At $14^{\prime \prime}$. & At $28^{\prime \prime}$. \\
\hline $\begin{array}{l}-6^{\prime \prime} \\
\cdot 5^{\prime \prime} \\
-4^{\prime \prime} \\
\cdot 3^{\prime \prime} \\
3^{\prime \prime}\end{array}$ & $\begin{array}{c}\text { lbs. } \\
12 \cdot 67 \\
" \\
" \\
" \\
"\end{array}$ & $\begin{array}{c}\text { lbs. } \\
186 \cdot 3 \\
" \\
" \\
" \\
"\end{array}$ & $\begin{array}{l}933 \text { f. s. } \\
932 " ” \\
881 " ~ \\
890 " ” \\
912 "\end{array}$ & $\begin{array}{r}0.5 \\
9.5 \\
11.4 \\
15.8 \\
29.4\end{array}$ & $\begin{array}{l}4 \cdot 6 \\
5 \cdot \\
4 \cdot 8 \\
4 \cdot 8 \\
6 \cdot 6\end{array}$ & $\begin{array}{l}3 \cdot 6 \\
3 \cdot 3 \\
3 \cdot 2 \\
3 \cdot \\
3 \cdot 7\end{array}$ \\
\hline
\end{tabular}

* Powder of 1859 , but not so hard pressed as that of 1860 .

This is one of the most important points Rodman has drawn atten. tion to, for in this way the maximum pressure can be reduced, and jet the initial velocity maintained.

As, however, there is a danger of carrying even this advantage to an extreme, I shall premise another set of experiments made by Rodman, which will serve to illustrate the point I refer to.

He tried statical pressure through the medium of soft wax in

* I have heard Professor Rankine give the explanation, in a lecture on Wares at Sencactle-on-Tyne. 
cylinders bored out like a gun on a small scale (sce Fig. 5). Various lengths of the bore were filled with the wax and the bursting pressures obtained. The calibro was 1.128 inches, and tho thickness of metal one calibre. The following are the results :-

\begin{tabular}{|c|c|c|c|}
\hline Length presicd. & $\begin{array}{l}\text { Mean bursting } \\
\text { pressure. }\end{array}$ & Length pressed. & $\begin{array}{l}\text { Mrean bursting } \\
\text { pressure. }\end{array}$ \\
\hline $\begin{array}{l}6 \text { inches. } \\
5 \text { " } \\
43 " \\
32 " \\
2 "\end{array}$ & $\begin{array}{ll}21 & \text { tous. } \\
26 \cdot 8 & " \prime \\
32 & " \prime \\
31 \cdot 8 & " \prime \\
39 \cdot 1 & \end{array}$ & $\begin{array}{lc}7 & \text { inches. } \\
2 & " \\
2 & " \\
2 & " \\
2 \cdot 0 & "\end{array}$ & $\begin{array}{l}27 \cdot 1 \text { tons. } \\
33 \Rightarrow " 4 " \\
29 \cdot 4 " \\
40 \cdot 3 " \\
42 "\end{array}$ \\
\hline
\end{tabular}

Rodman considers that these pressures are high owing to the want of porfect fluidity in tho wax. They serre, however, to show a law which is represented in Fig. 6, where the horizontal and rertical coordinates of the curre represent the lengths of bore and bursting pressures respectirely. The benefit to be derired from the operation of this law may be shortly stated thas: with two calibres the circumferential strength is increased by one-half, while bejond fire calibres no advantage is gained by it. It will be noticed, that if the powder burn rery slowly, the shot will more during the first and most important part of its course under a much smaller pressure than tho gun is capable of sustaining with a corresponding loss of velocity.

The maximum pressurc sliould be obtainod as soon as possible, and should not be allowed to subside too rapidly, but should be continued as nearly as possible in accordance with the curre giren above. The maximum pressure ought not, howerer, to be obtained so rapidly as to partake of the nature of a sudden pressure, i.c., it should not be obtained so rapidly as not to gire the metal of the gun timo to expand before it has reached its maximum. The law abore giren has also a very important bearing on the size of the bore of the gun, for, in addition to giving a smaller pressure per square inch, a larger bore will not throw tho pressure so far forward with the samo charge of powder.

\section{Committec on Explosires.}

Somewhat tardily in our own country this Committee has been appointed to consider, amongst other things, the question of most pressing importance before procceding with the manufacture of rery heary guns, viz., to find a powder which, in the monster ordnance we are about to construct, will give the greatest initial velocity of projectile with the least strain on the gun.

In our heary service guns, when R.L.G, powder is nsed, wo find the initial relocities decreasing with the size of the gun; thas-

Nature of gan ......7 7 inch, 8 inch, 9 inch, 10 inch, $600-\mathrm{pr}$.

Initial relocity...... 1458 1363, 1336, 1298, 1180.

This result is entirely due to tue use, with these guns, of powder 
Joumal R.U.S. Institition

Vol. 15.

P1.XIV.

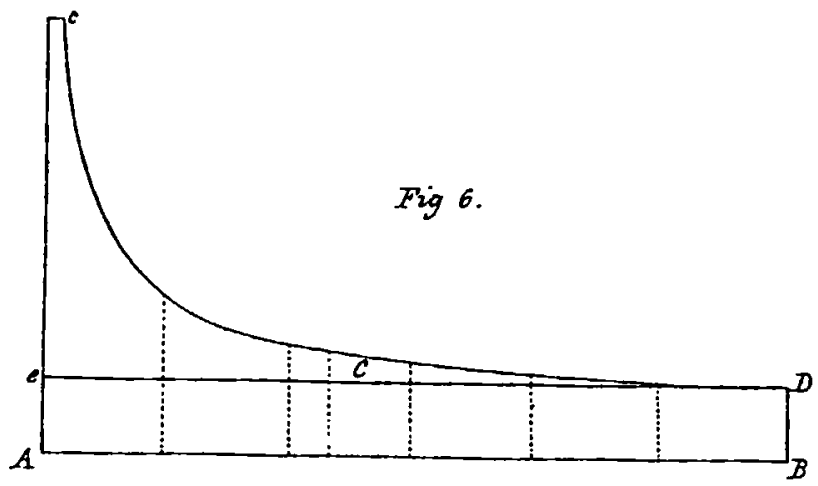

Fig 7.

Frig 8.

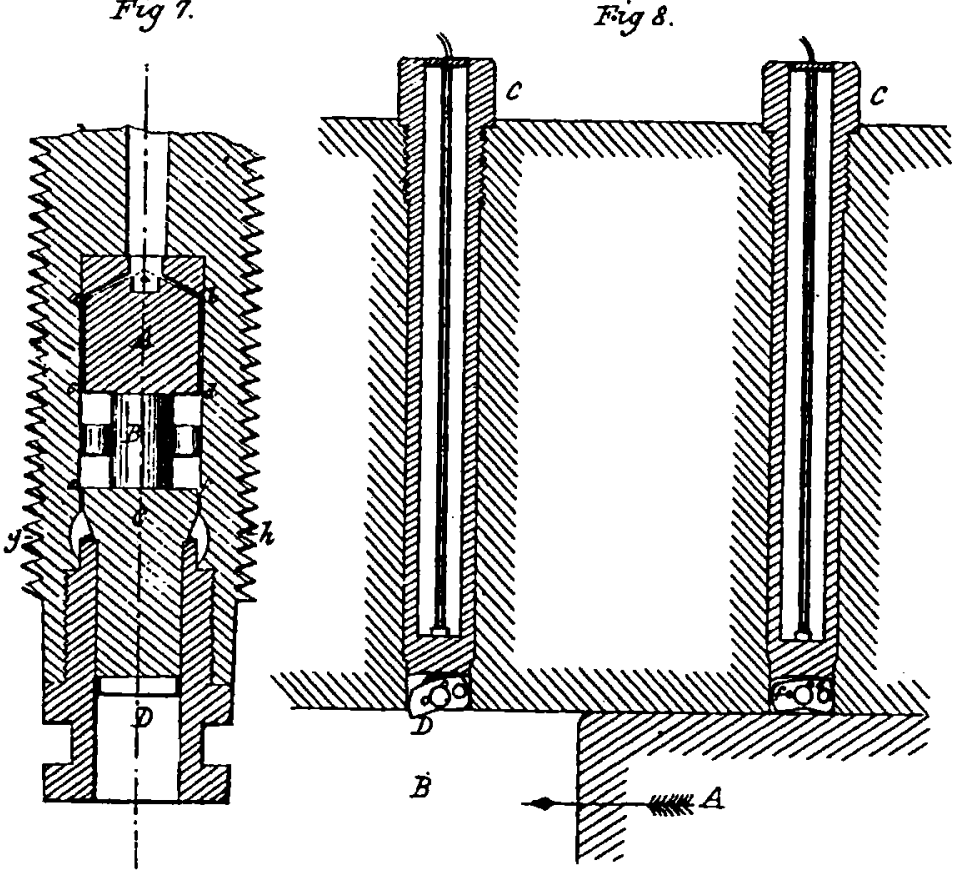


suitable only for smaller natures; for, if the guns are of the same construction and equally perfect manufacture, they will stand the same strains, and if tho strains be the same throughout corresponding lengths of bore the initial velocitics ought to be identical.

It is true no doubt that in leary guns the manufacture slightly deteriorates and the length in calibres has to bo decreased, but these are reasons, if we wish to retain the relocity and at the same time not orerstrain the gun, for making the law of pressure conform more instead of less closely to the strength of the gun as the various lengths of bore come under the infuence of pressure. Any departure from this will result either in a loss of initial velocity or cause an undue strain on the gun at some particular point.

Perfection would be attained by having a special powder snitable for cach nature of gun, but practically this cannot well bo carried out. It is of all the moro importance therefore that wo shonld bo provided with the fullest information on the sabject, that wo mas bo ablo to decide on some singlo porder suitable to all heary guns, or on two or more sorts, tho mixtaro of which will best answer the purposes required.

'To a great extent the Committeo have, in their investigations, followed in the footsteps of Rodman, i.e., they have endearoured to obtain the pressures as they actually occur in the bore, and, like him, they have adopted two methods of doing so.

Instead of his "pressure gauge" they use a "crusher gauge," a representation of which is given in Fig. 7 ; and, instead of estimating the pressure from the relocity of recoil of the gun, they do so from the relocity of the shot in the bore.

For this last purpose they make use of a "chronoscope," inrented by Captain Andrew Noble, late R.A., of Elswick. It notes tho moments of passing various points in the bore by electric sparks which ariso from the shot in its course causing projecting tools to shear wires in succession, as shown in Fig. 8.

Their experiments hare beci confined to four kinds of powder, viz., R. L. G., prismatic, pellet, and a new sort called pebble. The following results have been obtained with tho $8^{\prime \prime}$-incli gun by tho chronoscope:-

\begin{tabular}{|c|c|c|c|}
\hline Nature of poirder. & Charge. & Initial relocity. & $\begin{array}{l}\text { Marimum } \\
\text { pressure. }\end{array}$ \\
\hline 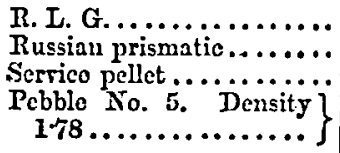 & $\begin{array}{l}30 \text { lb3. } \\
32 ", \\
30 " \\
35 "\end{array}$ & $\begin{array}{l}132.1 \text { f.s. } \\
1366 " \\
1333 " \\
1374 "\end{array}$ & 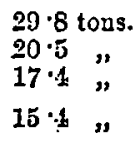 \\
\hline
\end{tabular}

The pressure cnrres during the initial stages of the sluot's motion are grisen in Fig. 9.

* Preliminary Report; Committec on Explosires. 
By the empirical formula I have derived from Rumford's cxperiments put in tho form of-

$$
y=\frac{P}{20+P}\left\{\frac{2}{l}+1\right\}
$$

I deduce the respective proportions of each of those powders which are consumed at the time of the maximum pressure to be R.L.G., 60 p.c., prismatic, 57 p. c., and pebble, 43 p. c.

The comparison of the prismatic and pebble curves is most suggestive, for though the prismatic charge is only $32 \mathrm{lbs}$. while the pebble is 35 , and though the prismatic begins to burn more slowly than the pebble, yet not only does the prismatic rery nearly maintain its relocity, but actunlly shows a greater pressure than the pebble, and that too at a point further forward in the gun.

It does not follow from this that at any point as regards time more prismatic than pebble is consumed, as will bo evident by a reference to the time curves given in Fig. 10, but, as regards space mored by the shot, it does. It may to a great extent be dao to the shape of the grain, which allows of greater acceleration of combustion. The fact that at the time it occurs the shot is moving less rapidly may also have something to do with it. But it is not to be left out of consideration that it may be due to another cause, for the low initial pressure would be favourable to ignition, and thus in the case of the prismatic, the whole charge may become more thoroughly ignited than in the case of the pebble, and though the combustion be less rapid at first, it may proceed with greater intensity afterwards. The greater velocity and less pressure of the pellet as compared with the R.L.G., may be similarly accounted for.

That there is room for an increaşed ncceleration of combustion, is cvident from the moderate amount of powder consumed at the time of the maximum. This supposition would also appear to explain the unaccountable fact of unconsumed grains being blown out of the gun when large charges are used, for the truth of which I can rouch. It is probable that the violent commotion set up in the chamber on first ignition of the charge is such that, more especially in long charges, portions are driven to the extremities and become so packed together by the enormous pressure, as to prevent thorough ignition of some of the grains.

I am aware that it is usual to consider that the amount of powder. consumed depends on the burning of each grain from the surface towards the centre, and that most of these curres might be explained in this way.

Sir Wm. Armstrong we hare seen explains the anomaly of the Pellet maintaining its velocity against R.L.G., by the loss of heat which the latter sustains during the initial stage of combustion. There are, however, as we shall see, other points not so easily explained on the theory usually adopted. Whaterer be the cause, the pebble is andoubtedly a better curve.than the prismatic, and shows some adrantages in addition to its less maximum; for the maximum pressure of the pebble takes place before that of the prismatic, and also thero is less appearance of suddenness in the former than in the latter. The prismatic gets ap the pressnre very slowly at first; but, when about to 


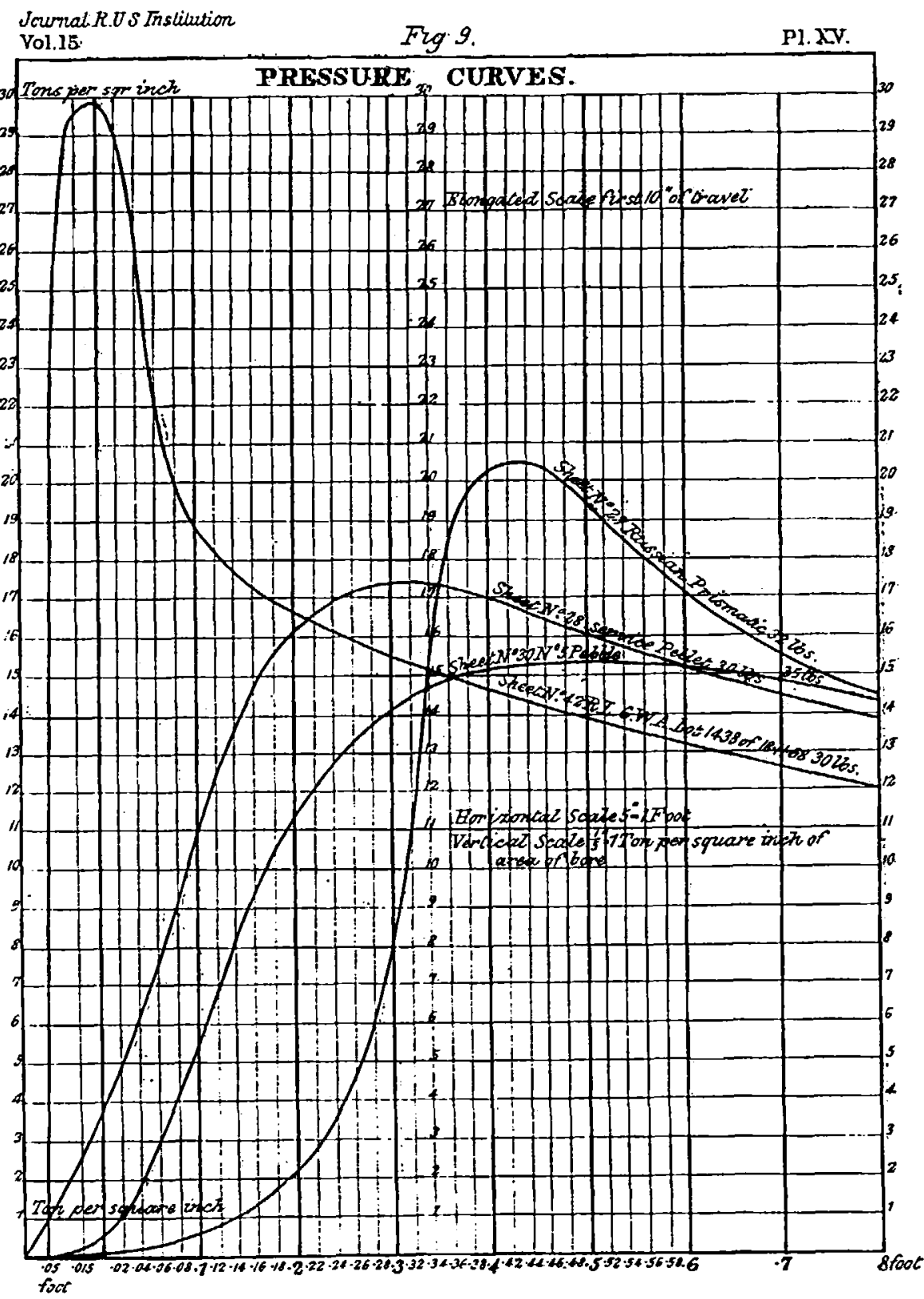


Jownal R.U.S Institution

Vol $] 5$.

Fig 10.

Pl.IVI

TIME CURVES.

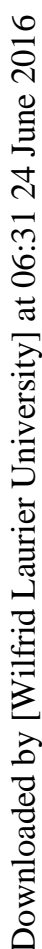

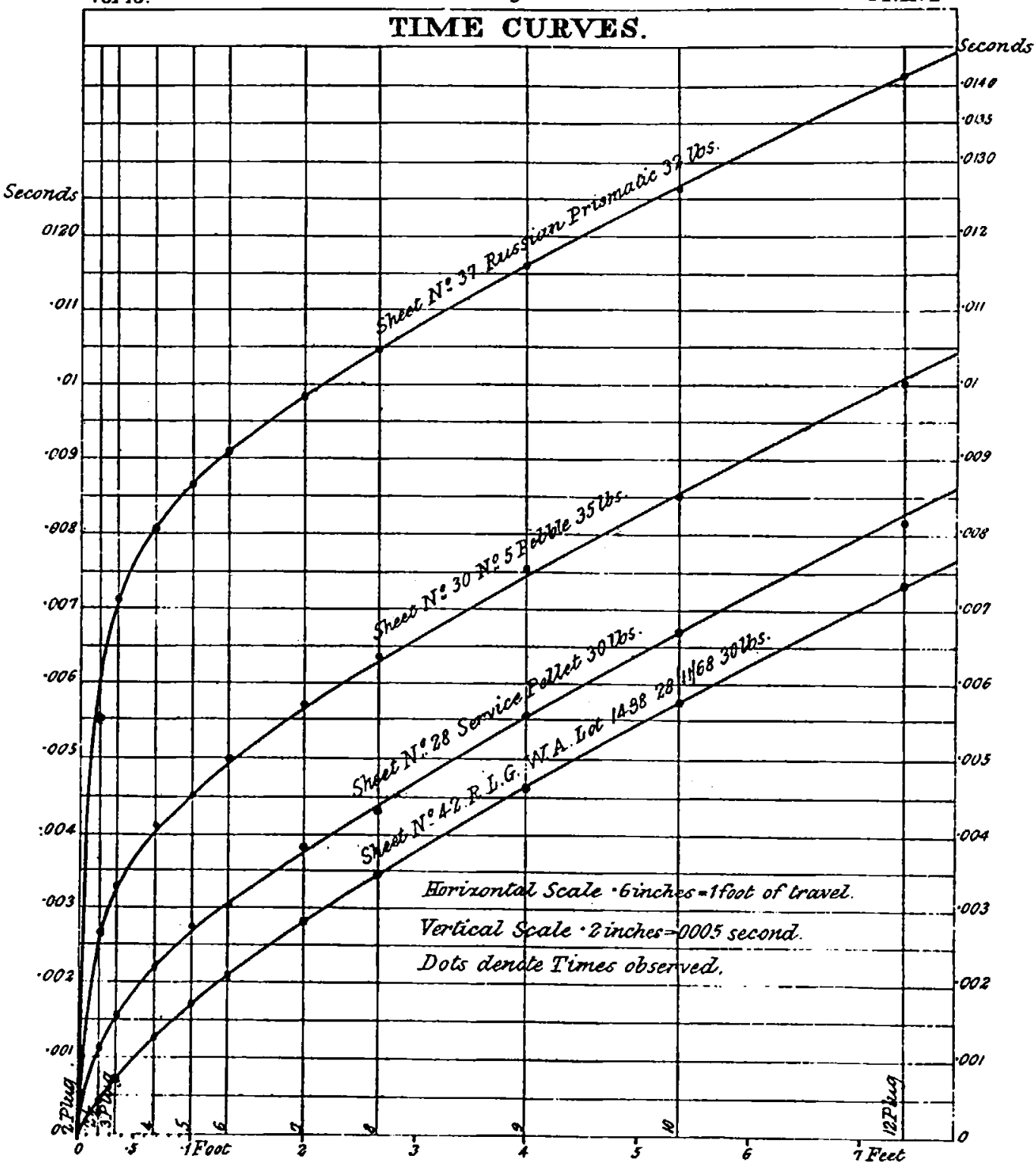


reach tho maximum, it takes a sadden rise, which may possibly be rapid enough to produce partially the effect of a sudden pressure. Its maximum is 20.5 tons; but suppose the pressure rises slowly up to 12 tons, and then suddenly becomes 20 , we should hare a pressure of 20 tons met by a resistance of $12,13,14,-20$ tons in succession, during which time the walls of the gun have acquired a velocity outwards, requiring a resistance of $20,21,22-28$ tons in succession to bring them to rest. The walls would again vibrate back to 12 tons, and out to 28 tons, increasing the injurious effects on the gun.

With the 10-inch gun,

"The principal average results, in varions series of six rounds each, are shown in tho following abstract, the pressure given being the highest as indicated by the crusher gauge."

\begin{tabular}{|c|c|c|c|c|c|}
\hline Nature of porder. & Density. & Charge. & Velocity. & Prcssurc. & Remarks. \\
\hline $\begin{array}{l}\text { R. L. G. ....... } \\
\text { Pellet............ } \\
\text { Prismatic Russian } \\
\text { Prismatic Ritter ... } \\
\text { Pebble .......... }\end{array}$ & $\left.\begin{array}{l}1 \cdot 742 \\
1 \cdot 733 \\
1 \cdot 67 \\
1 \cdot 677 \\
1 \cdot 66 \quad\{ \\
1 \cdot 66 \\
1 \cdot 732 \\
1 \cdot 782 \\
1 \cdot 732 \\
1 \cdot 782\end{array}\right\}$ & 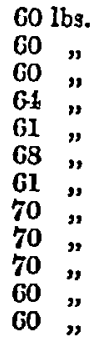 & $\begin{array}{l}1318 \text { f. s. } \\
1321 ", \\
1313 " \\
1364 " \\
1335 " \\
1425 " \\
1319 " \\
1416 " \\
1474 " \\
1432 \text { " } \\
1359 " \\
1298 \text { " }\end{array}$ & $\begin{array}{l}51 \\
43 \\
53 \\
25 \\
19 \\
29 \\
21 \frac{1}{2} \\
24 \\
29 \\
21 \\
21 \\
15\end{array}$ & $\begin{array}{l}\text { One round. } \\
\text { One round. } \\
\text { Uniform grain. } \\
\text { One round. } \\
\text { One round. }\end{array}$ \\
\hline
\end{tabular}

We here see the remarkable fertility of the sabject, the initial velocity being increased by more than 150 f.s., when pebllo powder is used, while the strain is very much reduced. The great importance of density is also shown, leading us to believo that this is one of the most important points to be taken into consideration in the manufacture of powder for very henvy guns.

With slow burning powders, the Committee state, the indications of pressure given by the "crushers" have been found to correspond rery closely with those deduced from the chronoscope, $\dagger$ but this is not the case with quick barning. powders nor even with slow bnrning powders when fired in large charges in very heavy guns. From Rodman's experience with his pressure gauge, we cannot doubt that the crusher is not in all cases to bo relied on. It scems to indicate intense local pressures which are greater as the point of their action is more distant from the point of ignition of the charge; greater at the extremities of the chamber than at the point of ignition in the middle, and greater when the crusher is at a distance from the bore than when

* Memorandum, 12th July, 1870 ; Committce on Explosires.

$t$ This can only refer to the chronoscopic pressures at and after the maximum. During the ascending branch of the curre the crushers can only show the maximum pressure. 
close to tho bore, amounting in somo cases to doublo the pressure dednced from the "chronoscopo" or .even morc. As an instance, the Committeo stato that, with R.L.G. in an 8-inch gan, when tho; "crusher" was close to the bore, the pressnre indicated was 22!. tons, bat, when at a distance, it was 40 tons per square inch.

The occurrence of these pressures would appear in the estimation of the Committeo to correspond with the notion already mentioned as having been inrestigated by Rolins, of tho gas first formed being suddenly arrested when at a high velocity and converted as by a blow into pressure. But when the crushers are pat in a second time, little or no further setting up takes place, as rould be the case if the action were due to a blow prodneed by the mass of gas in motion. Under such a supposition the intens, pressures would take place before the general maximum is attained, and it is difficult to conceive that the necessarily small mass of gas is sufficient to produce the results manifested.

It is moro reasonable to suppose that they occur at the moment when the general maximum exists, and may be superadded to it. In addition, it appears both from Rodman's experiments and those of the Committee, that when once the action is set up, it is continued through. out the bore, which wonld not be the case were it due to the velocities of the gases first ignited. This continuance of the action is also unfaroumble to the supposition that it is due to an intense general pressuro of the amount indicated, which, as shown by Rodman, would gradually subside as the gas expanded and produce no further vibration. It might, however, be explained were the general pressurc of the nature of water pressure which would suddenly subside with a very small motion of the shot, and so produce vibration by sudden cessation; and in support of this view it may be said there is a marvellous harmony in the fact that Rumford, Rodman, and the Committee all find these pressures manifesting themselres somewhere about 30 tons.

The apparently local nature of tho pressurcs might bo accounted for by the relief which would be given at those points where the gas could escape, sach as the rent and the base of the shot. The vibration howerer, would equally be set up by a moderate general pressure if it were suddenly applied, and which, acting on tho "crusher" and walls of the gun would, in the first instance, produce effects on each varying with their masses, tho spaces described, and the resistances, and afterwards set up an action which would be most felt by the "crushers," because they would partake both of their own motion and that of the walls of tho gan.

There is yet another supposition which would account for these pressures.

If the charge when ignited burn uniformly, the grains nearest the point of ignition will naturally bo in a more adranced state of combus. tion than those further awas.

A great pressure and temperaturo will arise causing increased com. bustion, which will be most felt where the greatest amount of powder remains to be consumed, and where it may be supposed to be a mass of half-burnt grains crushed to dust by the pressure procceding from the point of ignition, a condition most farourable for intensely rapid com- 
bustion. Thus sudden local pressures would be manifested at these points and be continued through the chamber by a sort of ware motion which, passing backwards and forwards, would manifest tho greatest effects where the direction of its motion was changed, viz., at the base of the shot and at the bottom of the borc. The facts that indentations are found in the bore at the base of the shot, and also that so much trouble has been found in preserving the bottom of the bores from the action of tae powder appear to favour this view. The continued action thronghout the bore also accords with it. On thi:: supposition the pressure would be often repeated, but the whole of the chamber would not be under its influence at the same time, and the structure of the gan would not bo so injuriously affected as tho more limited surfaces of the crushers.

These anomalous pressures would thus appear to be due to one or other of two causes, either a wave motion in the gas originated somewhat in the manner described, or a vibration or ware motion in the walls of the gun set up either by a very intense water pressure, or by a less intense gascous pressure suddenly applicd.

I lave long been farourable to the notion that the rave motion exists in the gas; but a consideration of the enormous pressure of which gunpowder is capable, and tho exceeding rapidity with which it is augmented, make mo doubtfal if the action bo not due to ribration in the walls of the gun, and of a very dangerous character. The practical point is to decide between these two views, and to determine whether the destructive action in the gun is comparable to the indications of the crushers.

These questions, though very necessary, are of such extreme delicacy that the chronoscope must fail to detect them, owing to the fact that it does not note the motion of the projectile continuously throughout the bore, but only from point to point, so that a pressure of great intensity but very short duration, may occur between two points of observation which cannot be separated from the general law of pressare, but must be absorbed in it, causing a modification.

The action in question we may assume to bo originated during the initial stages of the shot's motion, where the wires of the chronoscope are two inches apart. The maximum pressure is attained even with the slowest burning powder before the third wire is cut, so that only two spaces of time are measured at this important point. If we take into consideration that the pressures may vary very irregularly and very greatly during this part of the action, it will be seen that the difliculty of tracing it must be rery great.

The diffeulty of determining the pressure by the clronoscope, during the initial stages, is still further increased by the fact that the shot has to more somo distance before shearing the first wire, and that no record of time can be obtained between the first moving of the shot and the shearing of the first wire. Any error in assuming the space through which the shot has mored or the relocity it has nequired when passing the first wire, must affect the calculation of the pressure aftermards, up to the point at least where the maximum occurs.

In addition, any uncertain action of the cutters or deflexion of the 
sparks, might be sufficient to throw it out, and would not readily be de. tected because the velocity would be the same at any point, provided the area below the curve of pressuro were the samo up to that point. There would, however, be a difference in the total time, but, as has been noticed, the chronoscope does not note the time from the first starting of the shot, where the difference mainly arises.

It will be seen by reference to the pressure curves with the 8-inch gun, how closely the pebble curre would approximate to that of the prismatic, were the tensity increased so as to make the combustion slower at the commencement, and if this increase of density had also the effect of making the ignition more perfect, and the combustion afterwards more rapid. Density is considered by some as the most, if not the only important element to bo considered in the manufacture of porrder for very heary guns.

From a consideration of the various principles I have brought forward, I was quite prepared for the manifestation of somo very high pressures in the proof of the 35-ton gan. I am indebted to Colonel MFiller* for the following particulars of pressures obtained by crushers in the base of the shot:-

\begin{tabular}{|c|c|c|c|c|c|}
\hline $\begin{array}{l}\text { Charge } \\
\text { Pressure } \\
\text { Velocity }\end{array} \ldots \ldots \ldots \ldots \ldots \ldots \ldots$ & $\begin{array}{r}75 \\
17 \\
1163 \\
22\end{array}$ & $\begin{array}{r}100 \\
25 \cdot 4 \\
1237 \\
276\end{array}$ & $\begin{array}{r}110 \\
31 \cdot 8 \\
1303 \\
30\end{array}$ & $\begin{array}{r}120 \\
46 \cdot 3 \\
1361 \\
321\end{array}$ & $\begin{array}{l}130 \text { lbs. } \\
63 \cdot 7 \text { tons. } \\
13.4 \text { f. s. } \\
35 \text { inches }\end{array}$ \\
\hline
\end{tabular}

As the crushers in the base of the shot do not usually correspond in their indications with those of any crusher in the gun, a crusher plug was substituted for the rent and the clarge fired by electricity. The following results wero obtained when the powder was the service pebble, and the tube in the service position of rent:-

$\begin{array}{cccc}\text { Charge. } & \text { Velocity. } & \text { Vent crusher. } & \text { Shot crusher. } \\ 120 & 1300 & 28 \cdot 6 & 40 \cdot 4 \\ 120 & 1357 & 20 & 21 \cdot 7\end{array}$

Colonel Miiller considers from these indications that a powder which will give in charges up to 80 or 90 lbs. a pressure evenly distributed over the powder chamber, is liable to give severe local pressures in such charges as rrere used with the 35-ton gun. Now the point jet to be determined is how far we can afford to disregard these pressures, for unless we can disregard them, the gun, although undoubtedly the most powerful gun in the world, must either fail to accomplish its intended object, or a new powder must be provided. TVe maj, indeed, adrantageously increaso the calibre so as to reduce the columns of powder and shot; but alterations of this description with such a very heavy gun, entail considerable expense, and may perhaps be aroided by a systematic series of experiments beforchand to determine not only the best sort of powder to be used, but also the weight and calibre of the gan to be adopted.

\section{What Rejains to be Doxe.}

What remains to be done, is therefore to determine with greater

* Ono of the Committce on Explosires. 
ecrtainty the law of pressure during the first part of tho shot's motion through the bore, in order that it may bo made to approximate as closely as possible to the law of strength of the gun, without running any risk from sudden pressure or anomalous pressures of whatever description. No method of accomplishing this has as yet met with entire success. Rodman's velocimeter failed for want of delicacy. The chronoscope of Captain Noble cannot be relied on for the reasons given. Another attempt was made by General Mayerski, of the Russian artillery, who attached to the base of the shot a rod which ho passed through a hole in the breech of the gun. As the shot moved, the end of this rod was mado to breal two electric currents at varied distances with different nunds. It seems strange that he did not make it trice a curve on a revolving cylinder, for he would thus at least hare obtained what is most required, viz., a tracing for a very short space from the very starting-point of the shot. The connecting rod, however, broke, and his results are of no practical importance.*

Particular care must be given to determine, as far as possible, the nature of the anomalous pressures so often referred to, so as to know whether they are due to length of cartridge and position of point of ignition, or to some chemical or physical law. If the former, they may probably be prevented, but if the latter they may be expected to manifest themselres on the attainment and in continuation of somo definite pressure, and will have to be aroided.

The experiments, however, will not be complete if they merely tell us what is best adapted to any existing service gan. By a comparison of the results obtained with varied powders, borcs, charges, and projectiles, some laws must be established which will enable us to determine boforehand what powder, calibre, charge, and projectile will be best adapted to any contemplated new gun; for, if, when we make a new gun, we have not only to alter the bore, but also the powder, we shall land ourselves in an expenditure of money which will very soon ring the knell of our future monster artillery, and the ships will beat $u s$ in the race.

The precise nature of the powder to be adopted is not by any menns to be considered as definitely settled. The pebble powder which has been recommended by the Committee has given satisfactory results only as far as the 600-pounder, and there is reason to believe that with tho 700-pounder a new description will be required. It is not improbable that it will be found necessary to adopt two sorts of different densities, one of which shall bo suitable for the smallest of our heary guns, and the other for the heariest. Mixtures in different proportions, it may bo conceired, will meet the requirements of the intermediate natures. From past experience we should take a lesson not to rush on too hastily in an old groore, making large quantities of a powder which, though well adapted to present requirements, may soon become obsolete as the art of gun-making adrances, for if we do wo may again find ourselves

* Mémoire sur les experiences faites a l'establissement do Mr. Erupp a Essen au mois do Norembre, 1867, pour determiner les pressures des gaz de la pondré dans l'ame des bouches a feu; par M. Mayerski, Général Major, Membre du Comité de l'Artillorie Russe, 1869.

roL. $\mathrm{xy}$. 
with plenty of powder, but with very little of the precise nature we require.

\section{How To Do IT.}

The importance of determining the questions I have briefly sketcher out, will readily be recognized, but the question mas be asked, How are we to do it when so many hare failed? Wo must benefit by the experience of those who have gone before us, and, if possible, improve on it, taking care to avoid their failures. Rodman had a clear idea of how a systematic series of experiments ought to be carried out when he varied the length of clarge, column of shot, and dinmeter of bore. It is because Mr. Bashforth followed a similar principlo when he carried out his experiments with raried bores, charges, and projectile, to determine the resistance of the air, that he has met with such marked success. Had Rodman's pressure-gauges been as accurate and as sensitive to determine pressures as Mr. Bashforth's instrument was to determine time, we should not have had much more to do than accept his conclusions. But Rodman failed for want of an instrument to carry out his ideas. He has, however, shown us what is to be done. Let us but carry out his notions on the plan laid down by him, and we shall obtain results which will well repay a little trouble and some expense.

It would be necessary to have experimental guns of the strongest possible form of construction, and of varied calibres, say $3,5,7,9$, and, possibly, 11 inches.

Pebble powder being most likely to give satisfactory results, should first be tried. Density, also, appearing to be the most important element, should first be investigated. Two densitics of this powder might be used, 1.74 and 1.84. Commencing with density 1.74, it should bo fired first from the 3-inch gun, with varied clarges and projectiles, noting tho increase of pressure for each increase of charge and each increase of projectile, and taking care to note any manifestation of anomalous pressure.

The same powder should then be tried, in the same manner, with the 5 -inch gun, and the pressures noted, with tho view to find out whether they increased with the lengths of chargo and projectile in the same way as in the 3-inch gun, or at a more rapid rate.

The same should be done with the 7-inch gun, to see if the pressures were tho same, or increased at a still more rapid rate, and so on with the 9-inch and 11-inch guns if necessary.

Density 1.84 should bo tried in a similar manner, and in all probability will show that the pressures are less under similar circumstances, and that longer columns of powder and shot can bo fired with this powder than with density $1 \cdot 74$.

Any other density can be tried, if necessary, in order moro satisfactorily to elucidate the allowability of increase in column of powder and projectile with increase of density.

If equal columns of powder and projectile in all the gans give similar pressures, then the size of gun for any particular density of powder will be given by the length of the columns, but, if not, a modification must be made according to the influence of the size of the bore on the 
pressure. In the latter caso much light will be thrown on the relative values of big and small bores, especially if taken in connection with the known laws of the resistance of the air and the penetration of armour plates.

In this manner we shall not only be able to say what the pressure is with varied charges, calibres, and densities of powder, but we shall be able, from the laws which may be established, to calculate with tolerable accuracy what will be the pressures with larger charges and bigger guns, and what density of powder is suitable for cech.

Lastly, having fixed certain densities which are to bo manufactured, and what guns they are suitable for, wo may, if thought advisable, make some experiments to determine what mixture of these densities would give better results with intermediate gans.

This method of proceeding is founded on the sapposition that density will not fail us, but it may not be all that we require. If it fail us other methods of regulating and moderating the combustion of gunpowder might be tried.

It is possible that with our heaviest guns we may have not only to search for the very best description of powder, but also for the very best description of gun. IVe can obtain some very good practical information to guide us in fixing what is the maximum pressure which it is safo to use, for, by firing tho battering charges of our service guns in these experimental guns, wo can noto the pressure given, and adopt that as the maximum, which must not bo exceeded in any new gun of similar construction.*

I am indebted to Mr. Bashforth $\dagger$ for the suggestion that a gun with a morcable brecch, on the plan proposed by me a year ago, t would be the best means of carrying out these experiments. I may observe that of late I have rery much improred its construction, my object being to allow the brecelh to move right away, so as not to disturb the elevation. In this way there would be no shock on the carringe, and, with a 15-inch gun firing at $15^{\circ}$ eleration, the strain would be reduced from 1,000 tons to 100 tons at most. This enormous reduction of strain wonld make it exceedingly well adapted to the small gun-boats now being constructed to carry heary guns on platforms, which can be raised or lowered at will, on the plan inrented by Mr. Rendel, of the firm; of

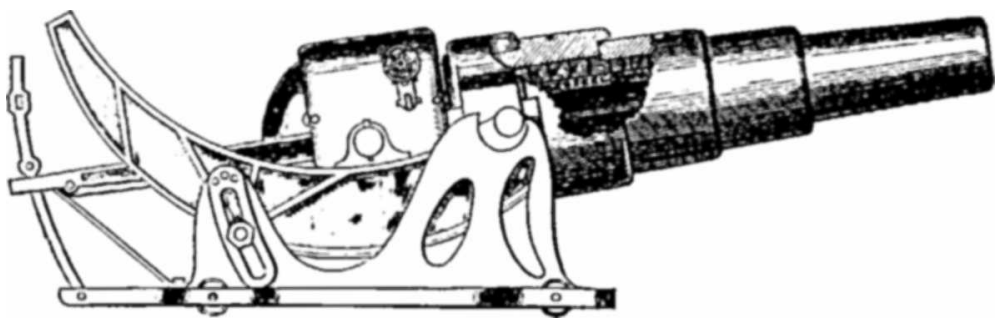

* Somo rery raluable information could also be obtained during these experiments, by firing through the Bashforth chronograph, which would show the amount of steadiness giren to raried lengths of projectile with raried relocities.

+ Professor of Applied Mathematics to the Adranced Class of Artillery Officers.

$\mp$ Vol. xir. p. 479 . 
Sir W. G. Armstrong and Co. Fig. 11 shows an elevation of the gun. The breech is run home on the guide bars, and thus the hollow part of the curve is thus bridged over.*

For the general law of pressure throughout, the bore the gun could be used in the form shown, for the slipping away of tho breech without resistance would give an accurate measure of the pressure which impelled it. It would have four times the delicacy of Rodman's velocimeter, because the space it would move wonld bo more than three inches while the shot traversed the bore. It would have this great adrantage over Captain Nolle's chronoscope, that tho tracing which could be obtained from it on a revolving cylinder would be a continuous curre from the rery starting of the shot, and not merely indicated by sereral points. It would also show the effect of lead-coating and riffing on the pressure.

But the great.advantage to be gained by this method would be the possibility of determining exactly the naturo of the anomalous pressures. The breech could be reduced in weight to any amount necessary to giro the desired sensitiveness, and the pressure could without difficulty be distinctly traced during the first stages of the shot's motion. For this purpose it might bo necessary to use a short gun, so as not to get up an extreme velocity. It would even be possible to hare breech and projectile of the same weight, and each double the weight of an ordinary shot, and the conditions of pressure would remain very much the same, because the two would move in opposite directions, each with a velocits equal to half that of an ordinary shot. And if the gun were not too long, a record could be obtained from both projectiles. This would be a means of detecting cven successive impulses of wave motion, if any such existed in the elastic fluid. It is probable, however, that such extreme delicacy would not be necessary, but that the law of pressure would be so traced during the initial stages as to give us all the inform. ation we desire.

But if it were desirable to test enormous pressures, so as to trace Rumford's law as far as possible, this method could bo adopted, for, by using a very short column of powder, and two very long columns of shot, the pressure would be very high, but, by rirtue of Rodman's law of increase of strength with diminution of length of chamber, our vers strong guns would withstand the explosion, and we should be able to go far above Rumford's pressures.

There is yet another use to which such a gun conld be applied, and which would be of very grcat advantage as confirming the results obtained in the way first indicated. For this suggestion I am again indebted to Mr. Bashforth. We have seen how very satisfactory Rumford's method of measuring the pressures was, as far as he was able to go, because it takes account only of absoluto pressure, and not of sudden pressure or wave motion.

There is a difficulty in applying Rumford's method to an ordinars gun, because the recoil of the gun would prevent the arrangement of

* A firing model was mado for mo at Elskick. It was fired sereral times with 2 oz. charge and $11 \mathrm{oz}$. of shot, the proportionate proof charge. The action was perfect. There was no escape of gas whaterer when a leather gab-check was used. 
the heary weight on the top of the stopper, but in a gun with a moveable breech this difficulty wonld not occur, because the barrel does not recoil.

If these two methods of measuring the pressure coincide, as I am confident they must, not only on my own mature consideration, but also because they mect tho approval of so able and successinl an experimenter as Mr. Bashforth, the results might be safely relied on, and laws wonld be established which would allow of extension, so as to tell with certainty what would be tho probable fate of any proposed new gun, and in future we should be able to justify our preference for big or small bores, not by the opinion of any individual, howerer eminent, but by the invariable laws of science, dedaced from experiment. No doubt such experiments would require a considerable expenditure of public money, but if we go on with big guns, as go on with big guns we must, they will result in a gigantic economy ; and, if these inrestigations were combined with what we already hnow, and what yet remains to be determined in the other branches of gunnery, our English artillery would, as heretofore, maintain its position as the first in the world. 